\title{
Community recovery following catastrophic iceberg impacts in a soft-sediment shallow-water site at Signy Island, Antarctica
}

\author{
Lloyd S. Peck ${ }^{1, *}$, Simon Brockington ${ }^{1}$, Sandra Vanhove ${ }^{2}$, Myriam Beghyn $^{2}$ \\ ${ }^{1}$ Natural Environment Research Council, British Antarctic Survey, High Cross, Madingley Road, \\ Cambridge CB3 OET, United Kingdom \\ ${ }^{2}$ Instituut voor Dierkunde, Mariene Biologie, Universiteit Gent, K.L. Ledeganckstraat 35, 9000 Gent, Belgium
}

\begin{abstract}
Ice disturbance is possibly the major structuring element of polar nearshore biological communities. Effects range from encapsulation by ice forming on rock substrata to gouging and trampling by bergs. Some 15 to $20 \%$ of the world's oceans are affected by this phenomenon, yet measurements of the extent of biological destruction from iceberg impacts and subsequent community recovery are very rare. Communities can be held at early successional stages, or even completely destroyed by scouring, and these effects occur from the intertidal to depths around $500 \mathrm{~m}$ in Antarctica. The wide scales of disturbance intensity are thought to add to the overall high levels of Antarctic benthic biological diversity, which has recently been shown to be similar to tropical areas. Data here indicate $>99.5 \%$ removal of all macrofauna and $>90 \%$ removal of most meiofauna by iceberg impact on a soft-sediment habitat at Signy Island, Antarctica. Species return was via locomotion, advection or larval recolonisation, and all 3 mechanisms worked on different timescales. Locomotion caused groups to return within $10 \mathrm{~d}$ of an impact. Storms with wind speeds around $100 \mathrm{~km} \mathrm{~h}^{-1}$ induced water movements intense enough to advect meiofauna to the $9 \mathrm{~m}$ depth site. However, it was only during the strongest storm which occurred during the study (maximum wind speed $148 \mathrm{~km} \mathrm{~h}^{-1}$ ) that water movements were powerful enough to redistribute small macrofauna such as the bivalve Mysella charcoti.
\end{abstract}

KEY WORDS: Antarctica $\cdot$ Iceberg $\cdot$ Community $\cdot$ Benthos $\cdot$ Macrofauna - Meiofauna - Diversity

\section{INTRODUCTION}

Biological diversity is currently a major topic of interest worldwide, especially in relation to environmental changes on global scales. Terrestrial biodiversity increases towards the tropics (Pianka 1987), and one of the best known trends in the marine environment is that of reduced biodiversity from tropical localities to the Arctic (Thorson 1957, Kendall \& Aschan 1993). Recently there was shown to be no similar trend in the southern hemisphere, mainly owing to high diversity in Antarctic waters (Clarke 1992, Poore \& Wilson 1993, Brey et al. 1994, Gray 1997). A factor which underpins biodiversity is habitat and environmental heterogeneity, and in some areas physical disturbance has been shown to enhance environmental or landscape hetero-

•E-mail: 1.peck@bas.ac.uk geneity (Huston 1979, 1994, Connell \& Keough 1985). In Antarctica ice disturbance is a dominant structuring factor in the marine environment (Dayton et al. 1970, 1994, Dayton 1990). Disturbance effects in Antarctic benthic marine systems vary with latitude, depth, site exposure and local current regimes. This produces a mosaic of habitat variability in terms of physical disturbance on both spatial and temporal scales, which may account for the unexpectedly high levels of biodiversity found. In this context it is surprising that few studies exist on the effects and recovery of species and communities in relation to disturbance from ice.

Natural disasters and environmental disturbance, including the effects of ice on biological communities, occur over wide ranges of spatial and temporal scales. Local freezing in temperate zones may be ephemeral, with little effect on organisms present, but glaciers and ice shelves may remove completely underlying biota and can persist for millennia. In shallow polar habitats 
a

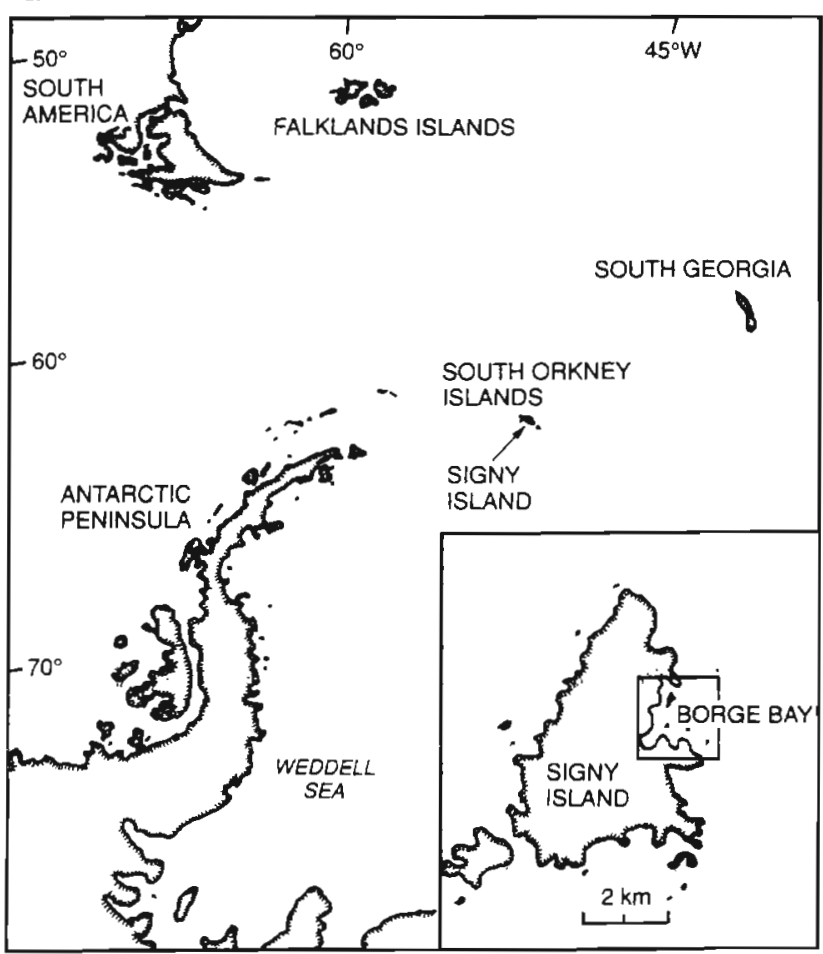

b

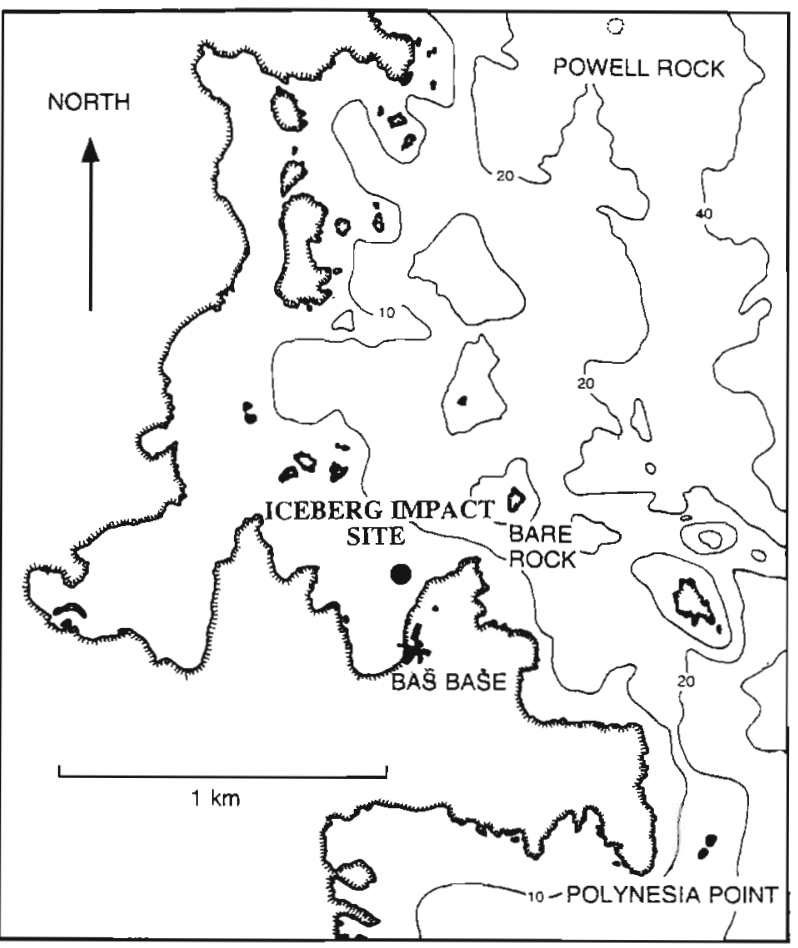

Fig. 1. Map showing (a) the position of Signy Island in the South Orkney Chain, off the Antarctic Peninsula, and (b) the position of the iceberg impact site in Borge Bay

(<50 m depth) hard substratum benthic community diversity and abundance are related to exposure and depth (Dayton et al. 1970, 1974, 1994, Dayton 1990, Arntz et al. 1994, Barnes et al. 1996), reflecting the frequency of ice disturbance. Such disturbance was much more widespread in recent geological history, with evidence of icebergs ranging as far as $41^{\circ} \mathrm{S}$ during the last glacial period (Bond et al. 1992). This implies that a significantly greater proportion of shallow marine environments worldwide were impacted by ice within the last $70000 \mathrm{yr}$, and illustrates the importance of ice effects over evolutionary timescales.

Icebergs impact the seabed to 400-500 $\mathrm{m}$ depth in polar oceans (Lien et al, 1989, Gutt et al. 1996). Community diversity is elevated in disturbed deep water areas compared with surrounding sediments (Dayton \& Hessler 1972), and Gutt et al. (1999) described higher between habitat (beta-) diversity due to iceberg scouring in the Weddell Sea. Enhanced diversity associated with disturbance at deep sites superficially conflicts with reduced diversity in shallow impacted hard substratum habitats. However, disturbance frequencies were estimated at $230 \mathrm{yr}$ in Antarctica, at depths between 100 and $500 \mathrm{~m}$, based on known organismal growth rates and estimated community development times for fauna inhabiting gouge marks (Gutt et al. 1996). Enhanced community diversity in deeper water was a result of increased habitat diversity combined with extended times between impact events which allowed longer recovery periods. On shallow hard substrata more frequent impacts hold communities at early successional stages (McCook \& Chapman 1991. Barnes 1995a,b), and in some Arctic sites disturbanceassociated faunas have been identified associated with scoured areas, as distinct from surrounding benthos (Conlan et al. 1998). Secondary factors, such as the development in scours of hypoxic seafloor brine pools, which produce lethal conditions for benthic and demersal organisms long after the impact event, have also been identified under certain conditions (Kvitek et al. 1998). Between the extremes a wide range of disturbance levels exists.

Despite the above there has been little work on the effects of icebergs on shallow soft sediment communities, and no data exist on the timescales or mechanisms of community recovery following iceberg impacts. Here we present such data following a scouring event at $9 \mathrm{~m}$ depth at Signy Island, South Orkney Islands.

\section{MATERIALS AND METHODS}

Initially an iceberg with a maximum height of 3 to $4 \mathrm{~m}$ was observed on its track on the south east side of Factory Cove, Signy Island, South Orkney Islands, until it grounded near Berntsen Point $\left(60^{\circ} 42^{\prime} 25^{\prime \prime} \mathrm{S}\right.$, 
$45^{\circ} 35^{\prime} 20^{\prime \prime} \mathrm{W}$ ) in a depth of $9 \mathrm{~m}$ (Fig. 1). It remained grounded for approximately $36 \mathrm{~h}$ and then drifted away to the northwest. An impacted area roughly $30 \mathrm{~m}$ in diameter was left behind. Samples were taken from the impacted site and a control (undisturbed) site $5 \mathrm{~m}$ away from the impact event within $24 \mathrm{~h}$ of the departure of the iceberg, and on Days 10, 20, 30, 50, 78, 102, 150,200 and 250 after the event. The whole field sampling period lasted from 18 December 1993 to 3 August 1994. A second iceberg impact was monitored in September 1994 at another site in Factory Cove, but $500 \mathrm{~m}$ distance from the first grounding. At the second site no meiofaunal analyses were made, and only the immediate effects of the iceberg impact were measured.

Samples for macrofauna were collected from $0.25 \mathrm{~m}^{2}$ quadrats using a suction sampler fitted with a $1 \mathrm{~mm}$ mesh retaining bag (Luxmoore 1981, Peck \& Bullough 1993). Two replicate samples were taken from the impact site on each date sampled. Replicate samples were also taken from the control site on Days 1 and 175. After collection material was returned to the laboratory, sorted and counts made immediately. Samples for meiofauna analysis and material for sediment organic content assessments were taken from sites adjacent to the macrofaunal sampling sites. They were obtained using $5 \mathrm{~cm}$ diameter acrylic coring tubes which were pushed into the sediment and capped before extraction. Again duplicate samples were taken and material collected this way was preserved in $4 \%$ formol seawater and transported to Belgium for analysis. Analyses of organic content were made on cores collected as above. The top $10 \mathrm{~cm}$ of sediment was removed and either analysed whole or passed through graded sieves to allow organic analysis of different sediment size fractions. Organic contents were assessed as the difference in mass between samples dried to constant weight at $60^{\circ} \mathrm{C}$ and ignited in a muffle furnace at $475^{\circ} \mathrm{C}$ for $24 \mathrm{~h}$.

\section{RESULTS}

At Signy Island the iceberg impact removed $>99.5 \%$ of all macrofauna at an 8 to $10 \mathrm{~m}$ depth soft sediment site. $100 \%$ of 6 groups (bivalves: Yoldia eightsi, Cyamiomactra laminifera and Laternula elliptica; nephtyid polychaetes; isopod: Serolis polita; and gastropod: Eatoniella sp.), 96.0\% of amphipods and $96.3 \%$ of the bivalve Mysella charcoti were removed (Fig. 2). Amphipods were predominantly of the genus Cheirimedon (G. Chapelle pers. comm.), but identification to species was not conducted for all samples. Abundances in controls of individual groups ranged to $78000 \mathrm{~m}^{-2}$ for the small ( $<3 \mathrm{~mm}$ length) bivalve $M$. charcoti.
At a second grounding event (data not shown), $500 \mathrm{~m}$ from the primary study site in September 1994, 9 mo after the first impact, only the immediate effects of the impact were measured, but there was again $100 \%$ removal of 6 of the 8 most common macrofaunal groups (Yoldia eightsi, Cyamiomactra laminifera, Laternula elliptica, Serolis polita, nephtyid polychaetes and Eatoniella sp.). Removal of the other 2 groups (Mysella charcoti and serolid isopods) was $>97.7 \%$ at this second site. Samples taken $5 \mathrm{~d}$ post impact at the second site showed no change from Day 1.

Meiofauna numbers were also dramatically reduced following the first impact event (Fig. 2). Meiofaunal densities at control sites were similar to those from a nearby study of meiofauna in Factory Cove (Vanhove et al. 1998). Over $90 \%$ of all meiofauna groups (nematodes $=98.5 \%$, ostracods $=98.1 \%$, bivalves $=96.0 \%$, turbellarians $=94.6 \%$, nauplii $=92.3 \%$ ) except copepods $(86.4 \%)$ were removed. Nematoda were most affected with a $98.5 \%$ reduction in numbers, from in excess of 1 million to less than 10000 per core sample.

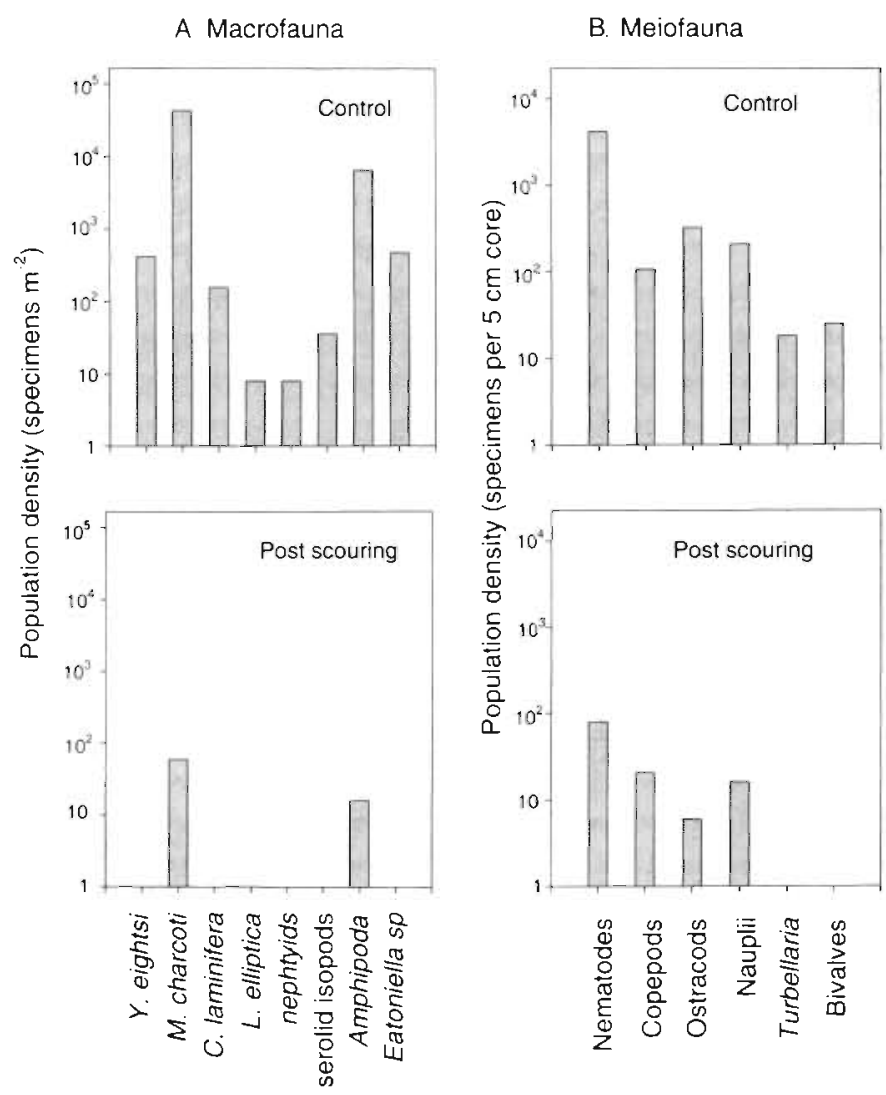

Fig. 2. Effects of iceberg scour on organismal abundance. (A) Macrofaunal abundances for the 8 most common taxa from control sites (unimpacted values) and following the scouring event (note logarithmic axes). (B) Control and post iceberg impact abundances (specimens $\mathrm{m}^{-2}$ ) for the 6 most common meiofaunal groups (note logarithmic axes). Data are only for the first impact site. No collection was made for meiofauna following the second impact 
A. Macrofauna

Retum via locomotion
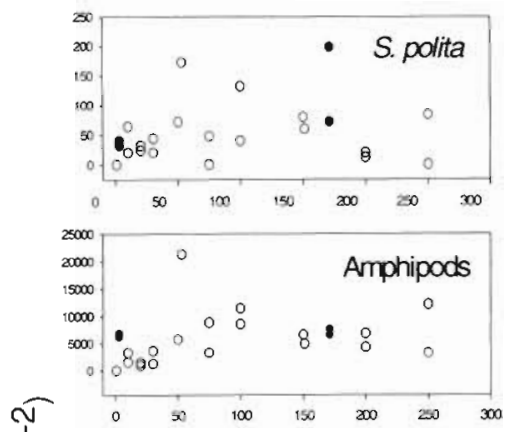

T.
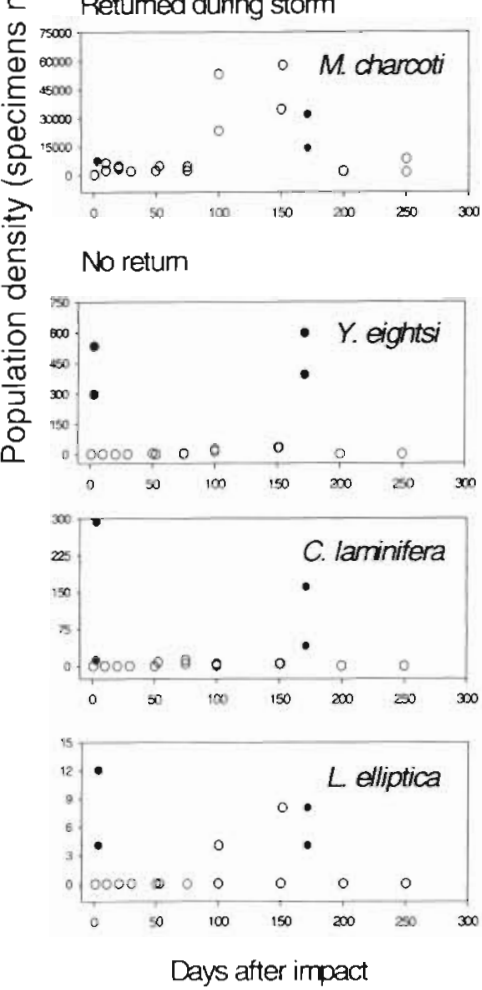

Fig. 3. Timings of return of faunal groups following an iceberg impact. Organismal density is plotted against day after the impact event. (0) Impact area values, $(\bullet)$ densities at the control site. Data shown are for the period following the first impact only. (A) Macrofauna. Data shown are for the most common species present. (B) The most common meiofauna groups (see Fig. 2) all returned 20 to $30 \mathrm{~d}$ after the impact. Numbers varied somewhat after this time, because of seasonal factors. Other meiofauna groups (including turbellarians and halacarids) were present in some samples, but in too small numbers for analysis

Recovery of faunal groups after the impact was indicated by abundances in samples collected during the $250 \mathrm{~d}$ following the scouring event (Fig. 3). Data shown in Fig. 3 are for the commonest groups present only. Other groups recorded during the study were in small numbers, or were aberrants normally inhabiting rocky substrata. These included pycnogonids, gastropods of the genera Lissarca, Laevilacunaria, Margarella and Nacella, sabellid and spirorbid polychaetes, and priapulids. Earliest recovery was by amphipods and the isopod Serolis polita, both motile macrofauna, which showed significant recolonisation within $10 \mathrm{~d}$ of the iceberg departing. None of the other macrofauna showed a significant return to the site within the first $100 \mathrm{~d}$ after the scouring event. The second group to return was meiofauna. Nematodes, ostracods, nauplii and bivalves $<1 \mathrm{~mm}$ length all returned between Days 20 and 30 after the impact event (Fig. 3), when their numbers were not significantly different from control values (paired $t$-test, $T=1.39, \mathrm{n}=10, \mathrm{p}=$ 0.197). Numbers of the small bivalve Mysella charcoti, which grows to approximately $3 \mathrm{~mm}$ length, returned to control levels in the sample taken $102 \mathrm{~d}$ after the iceberg impact. This was the third group to recover.

Numbers of the final group which could be identified showed no significant recovery during the $250 \mathrm{~d}$ experimental period (Fig. 3). This category comprised 3 moderate to large sized bivalve molluscs, all $>5 \mathrm{~mm}$ length (Cyamiomactra laminifera, Yoldia eightsi and Laternula elliptica). There were small variations in numbers sampled in this group, and on Day 150 after impact 2 specimens of the largest bivalve present, L. elliptica, were collected. However, these were close to a rock outcrop within the scoured area.

Fig. 4 shows the maximum wind speeds of storms which occurred in Factory Cove throughout the study. Meiofauna recovery (between Days 20 and 30 post scouring) coincided with the first storm with wind speeds in excess of $100 \mathrm{~km} \mathrm{~h}^{-1}$, on Day 23. Return of the small bivalve Mysella charcoti on Day 102 immediately followed the largest storm recorded during the study (on Day 100) when a maximum wind speed of $148 \mathrm{~km} \mathrm{~h}^{-1}$ was recorded. The sampling date was delayed to Day 102 because of the intensity of the storm. Species usually only associated with hard substrata (including the gastropod Margarella antarctica and sabellid polychaetes) were also advected to the scouring site by this large storm. These species were not observed in the scoured area following lesser storms. 
Unexpectedly, sediment organic content was unaffected by iceberg gouging either immediately after impact (ANOVA, 1,11 df, $F=1.94, p=0.19$ ), or 150 to 200 d later (ANOVA, 1,11 df, $F=1.34, p=0.28$; Fig. 5). There was also no trend in total organic content throughout the study (regression, slope $=-0.0014, t=$ $-0.70, p=0.50$ ). However, this was because organic matter in the smallest size class $(<0.25 \mathrm{~mm})$ dominated, which did not vary during the study (regression, slope $=0.00054, t=0.96, p=0.36$ ). Organic content of all of the larger size classes except the $>5 \mathrm{~mm}$ fraction declined seasonally from summer to winter (regressions: $>5 \mathrm{~mm}$ fraction slope $=-0.0261, t=-1.53, \mathrm{p}=$ $0.15,1$ to $5 \mathrm{~mm}$ fraction, slope $=-0.023, t=-1.94, \mathrm{p}=$ $0.046 ; 0.5$ to $1.0 \mathrm{~mm}$ fraction, slope $=-0.011, t=-2.24$, $\mathrm{p}=0.38 ; 0.25$ to $0.5 \mathrm{~mm}$, slope $=-0.0044, t=-2.83, \mathrm{p}=$ 0.016; Fig. 5). Total organic content at recently impacted sites is therefore the same as in control areas, suggesting little decline with depth in the sediment.

\section{DISCUSSION}

Icebergs affect soft substrata in 3 main ways. They plough the seabed, which forces surface layers away from the point of contact; they trample it, whereby icebergs rock backwards and forwards crushing underlying organisms and seabed; and water flowing around icebergs either caused by movements of the berg, natural oceanic currents, or salinity induced water movements can resuspend and transport sediment (Reimnitz \& Barnes 1975, Carey \& Ruff 1977). These phenomena are all capable of removing or translocating macrobenthos

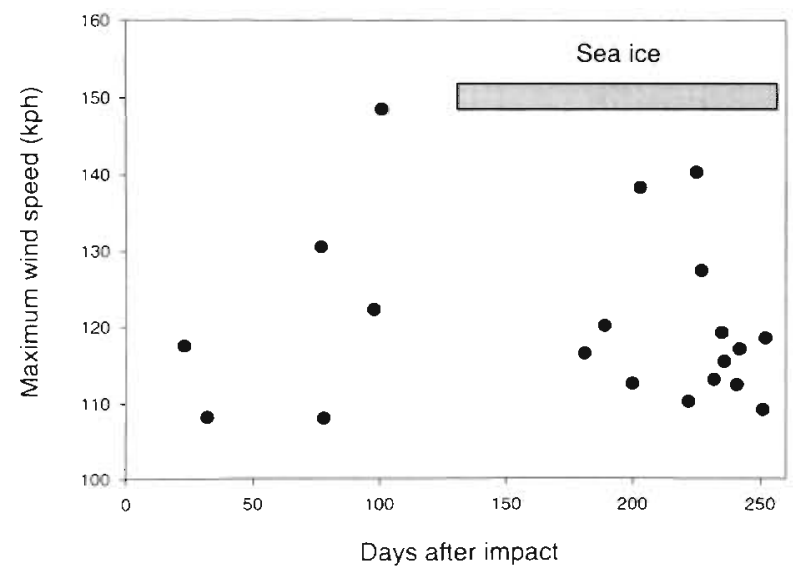

Fig. 4. Maximum wind speeds of storms at the iceberg impact site between 18 December 1993 and 3 August 1994. The site was sheltered from the west and southwest. Only storms with wind directions between $330^{\circ}$ and $180^{\circ}$ were, therefore, included. Sea-ice presence is indicated by the solid horizontal bar, and the site was covered from approximately Day 130 onwards, which reduced dramatically any storm effects after that date
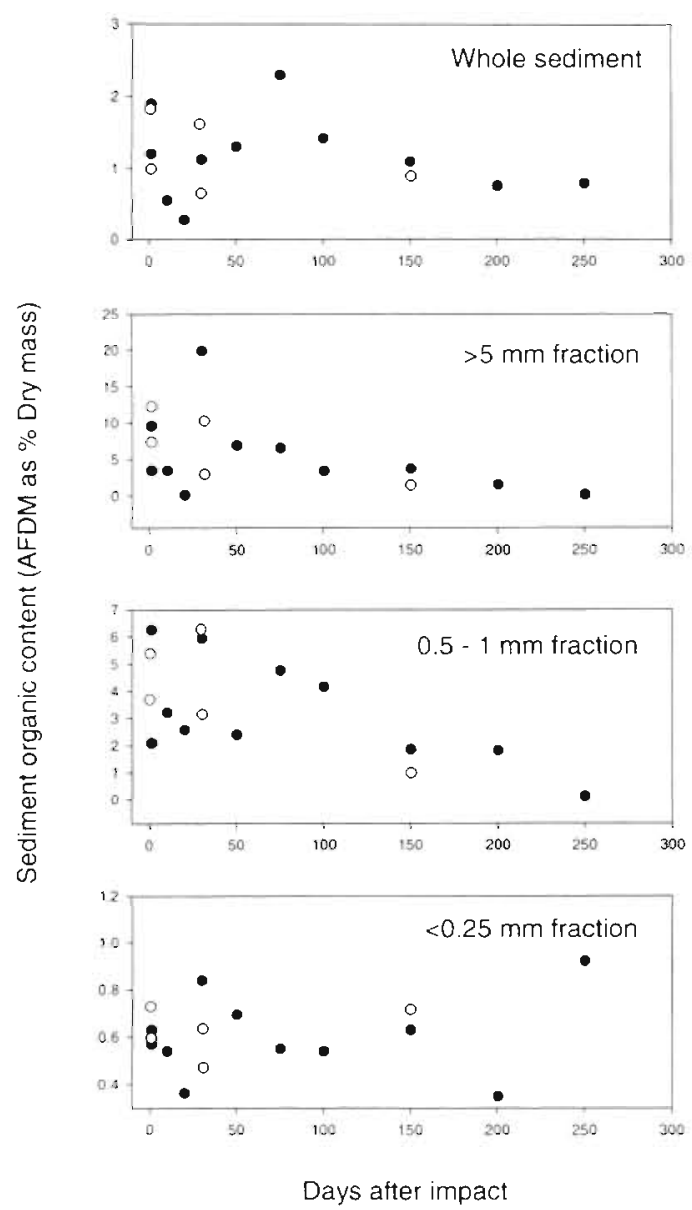

Fig. 5. Organic content of sediment at the impact site (ashfree dry mass, AFDM, as \% dry mass, •), and from nearby controls (0). Values shown are whole sediment and the size fractions $>5 \mathrm{~mm}, 0.5-1 \mathrm{~mm}$ and $<0.25 \mathrm{~mm}$. Size fractions $1-5$ $\mathrm{mm}$ and $0.25-0.5 \mathrm{~mm}$ are not shown, but were similar to the $0.5-1 \mathrm{~mm}$ fraction

from under or around an iceberg. However, meiofauna removal on the scale seen here by trampling or currents produced by movement of a berg of this size is unlikely, although both probably occurred on smaller scales, because the berg remained grounded for over $36 \mathrm{~h}$. Ploughing was therefore likely to be the major effector. Plough marks over $30 \mathrm{~m}$ wide and $5 \mathrm{~m}$ deep have been recorded (Barrie 1980), exposing sediment beyond depths where multicellular organisms are abundant. The scouring at Signy Island, in addition to killing large numbers of macrofauna by trampling, clearly exposed sediments containing few meio- or macrofauna, even though the post-impact depression was only 50 to $75 \mathrm{~cm}$ deep.

The return of species to an impacted site, and the recovery of communities is controlled by several factors. The earliest to return to sites are those that are motile, as shown by amphipods and isopods (Fig. 3). Other groups depended on external forces, or new recruitment via larval forms to recolonise the site. The 
return of meiofauna was regulated by the magnitude of storm induced water movement close to the seabed, and were advected back to the experimental site by the first storm after the impact event (Figs. $3 \& 4$ ). Meiofauna have been shown to be transported passively on strong water currents elsewhere (Sherman \& Coull 1980, Fleeger et al. 1995). Macrofaunal densities were not affected by the storm which advected meiofauna to the impact site. Following the early recolonisation by motile forms, the only change in macrofaunal density followed the largest storm of the year (study Day 100; maximum wind speed $148 \mathrm{~km} \mathrm{~h}^{-1}$, maximum 5 min mean winds $>100 \mathrm{~km} \mathrm{~h}^{-1}$ ) when large numbers of the small bivalve Mysella charcoti ( $<3 \mathrm{~mm}$ length) were advected to the site (Fig. 3) by intense storm induced water movements. Water column turbulence of this magnitude clearly redistributes small nonattached macrobenthos around shallow bays in Antarctica. It should be noted that this type of organism is not moved by moderate storms and strong turbulence is needed to redistribute species like $M$. charcoti around the seabed, as none of the previous storms (some with wind speeds $>100 \mathrm{~km} \mathrm{~h}^{-1}$ ) succeeded in doing so. A continuum of redistribution of organisms probably exists between light water movement and major storms, and at least 2 levels have been demonstrated here. Between the 100 and $150 \mathrm{~d}$ samples seaice covered the site and storm effects were much reduced until the end of winter (after Day 250).

Large bivalves must recolonise impacted sites via larval dispersal. This is supported by a study of growth in Yoldia eightsi at Signy Island close to the impact site which found regularly impacted areas had populations dominated by small specimens ( 2 to $10 \mathrm{~mm}$ length) at densities up to $1460 \mathrm{~m}^{-2}$, whereas less disturbed populations comprised more mature individuals (Peck \& Bullough 1993). It was suggested that recruitment and population structure were maintained by iceberg scour releasing new sites for colonisation, and balancing areas dominated by adults which inhibited larval settlement (Peck \& Bullough 1993). It was somewhat surprising here that $Y$. eightsi did not return during storms. It is mobile to a degree, pushing its way through surface sediment, and has a light shell. Small specimens, which can occur in very high densities (Peck \& Bullough 1993) were expected to be returned by violent water movements. However, on disturbance $Y$. eightsi burrows and behavioural mechanisms may preclude its return during storms. Three major mechanisms have, therefore, been identified for the recolonisation of iceberg impacted sites on shallow soft sediments: locomotion, dispersal by water currents and via larval recolonisation. The 3 methods act on different timescales.

It has been stated that community recovery from iceberg disturbance requires many years (Picken 1985).
In addition colonisation of settlement plates in Antarctica is at least an order of magnitude slower than at temperate or tropical sites (Barnes 1996, StanwellSmith \& Barnes 1997), and strong interannual variability may be characteristic of recruitment in polar latitudes (Dayton 1989). However, recovery following the iceberg impact at Signy Island varied between faunal groups, both in method and timing (Fig. 3), with some groups returning in a matter of days.

Quantitative assessments of the effect of iceberg scour on shallow biological communities are absent (Clarke 1996). Richardson \& Hedgepeth (1977) observed iceberg scouring at Arthur Harbour, Anvers Island, but no quantitative measurements were made. They suggested 5 recovery phases following impacts. Initially a depression formed which filled with macroalgal fragments from vicinal rocky areas. Motile species aggregated to feed on the macroalgae and predators returned to exploit the newly established communities. The depression finally filled via sedimentation from pelagic productivity. Locomotion and advection were major influences controlling recovery in both studies. Clearly in some conditions macroalgal input can be important, but these conditions are probably rare because of the relative scarcity of large macroalgal stands in high Antarctic latitudes, however, locomotion, advective water movement and larval settlement will be of major importance at all sites.

Several factors control soft-bottom community structure, diversity and organismal biomass in polar regions. The most important are disturbance, sediment type and nutrient supplies (Dayton et al. 1970, 1994, Gallardo 1987, Barnes et al. 1996). In stable productive habitats macrofaunal abundances can be extreme, with animal densities $>150000 \mathrm{~m}^{-2}$ (Gallardo \& Castillo 1969, White 1984) and predation can be important in maintaining such high density assemblages (Oliver \& Slattery 1985). Clearly the importance of each factor varies between sites along a continuum from stable high productivity to highly disturbed, low productivity. These are the criteria which have been shown to be of importance in regulating diversity in biological communities in all ecosystems, and have been synthesised into the nonequilibrium 'intermediate disturbance hypothesis' (Paine \& Vadas 1969, Connell 1978, Huston 1979, 1994, Connell \& Keough 1985). The hypothesis is based on reduced diversity at high or low levels of disturbance, where disturbance is defined in terms of mortality of the organisms present, and can be any mortality factor. The range of physical disturbance in Antarctic benthic systems is extreme, from continual abrasion and ice encapsulation to minor effects which only occur with a frequency of hundreds of years. This is a major factor leading to the observations of high biodiversity in Antarctic marine benthos (Dearborn 
1968, Richardson \& Hedgepeth 1977), and there is support for the intermediate disturbance hypothesis in the enhanced levels of diversity seen at depths between 5 and $50 \mathrm{~m}$, where physical disturbance levels are intermediate between highly impacted shallow sites and infrequently disturbed deep water localities (Dayton 1990, Arntz et al. 1994, Dayton et al. 1994, Gutt et al. 1996). Longer term environmental cycles such as those recently found to enhance deep sea diversity (Cronin \& Raymo 1997) will also enhance habitat diversity in polar oceans on temporal scales.

On Antarctic criteria the system at Signy Island is light to moderately disturbed and productive, which suggests it may be representative of many maritime Antarctic soft sediment environments. The identified mechanisms of recovery from iceberg scouring, locomotion, storm washing and larval recruitment should therefore be widespread and common. During glacial periods iceberg scoured conditions are likely to be amongst the most common in shallow benthic habitats, and the adaptations described here the most common ecological adaptations in shallow marine environments. It may also be the case that species adapted to regular physical disturbance of the type described here may be more resistant to disturbances of human origin than would be expected.

Acknowledgements. We thank the staff at the British Antarctic Survey Signy Island Research Station for assistance during sampling, especially R. W. Wood, R. Manning. L. Thomson, M. Chalmers, P. Bramham and D. Stanwell-Smith. A. Clarke gave useful comments on early drafts and extensive and valuable critical comment was made by J. Gutt during the review process. Meiofaunal analysis work was supported by a research grant from the Institute for the Encouragement of Scientific Research in Industry and Agriculture (IWT), and the Scientific Research Programme on Antarctica-Phase III from the Belgian State-Prime Minister's Federal Office for Scientific, Technical and Cultural Affairs (DWTC).

\section{LITERATURE CITED}

Arntz WE, Brey T, Gallardo VA (1994) Antarctic zoobenthos Oceanogr Mar Biol Annu Rev 21:341-453

Barnes DKA (1995a) Sublittoral epifaunal communities at Signy Island, Antarctica: I. The ice foot zone. Mar Biol 121. 555-563

Barnes DKA (1995b) Sublittoral epifaunal communities at Signy Island, Antarctica: II. Below the ice foot. Mar Biol 121:565-572

Barnes DKA (1996) Low levels of colonisation in Antarctica the role of bryozoans in early community development. In Gordon DP, Smith AM, Grant Mackie JA (eds) Bryozoans in space and time. Proc 10th Int Bryozool Conf. National Institute of Water \& Atmospheric Research Ltd, Wellington, $\mathrm{p}$ 19-28

Barnes DKA, Clarke A, Rothery P (1996) Colonisation and development of encrusting communities from the antarctic intertidal and sublittoral. J Exp Mar Biol Ecol 196:251-265
Barrie JV (1980) Iceberg-seabed interaction (Northern Labrador Sea). Ann Glaciol 1:71-76

Bond $G$, Heinrich $H$, Broecker W, Labeyrie L, McManus J Andrews J, Huon S, Jantschik R, Clasen $S$, Simet $C$, Tedesco K, Klas M, Bonani G, Ivy S (1992) Evidence for massive discharge of icebergs into the North Atlantic Ocean during the last glacial period. Nature 360:245-249

Brey T, Klages M, Dahm C, Gorny M, Gutt J, Hain S, Stiller M, Arntz W, Wagele JW, Zimmerman A (1994) Antarctic benthic diversity. Nature 368:297

Carey AG, Ruff RE (1977) Ecological studies of the benthos in the Western Beaufort Sea with special reference to molluscs. In: Dunbar MJ (ed) Polar oceans. Arctic Inst N America, Calgary, p 505-530

Clarke A (1992) Is there a latitudinal diversity cline in the sea? Trends Ecol Evol 7:286-287

Clarke A (1996) The distribution of Antarctic marine benthic communities. In: Ross RM, Hofmann EE, Quetin LB (eds) Foundations for ecological research west of the Antarctic Peninsula. American Geophysical Union, Washington, DC, p 123-133

Connell JH (1978) Diversity in tropical rainforests and coral reefs. Science 199:1302-1310

Connell JH, Keough MJ (1985) Disturbance and patch dynamics of subtidal marine animals on hard substrata. In Pickett STA, White PS (eds) The ecology of natural disturbance and patch dynamics. Academic Press, Orlando, p $125-147$

Conlan KE, Lenihan HS, Kvitek RG, Oliver JS (1998) Ice scour disturbance to benthic communities in the Canadian High Arctic. Mar Ecol Prog Ser 166:1-16

Cronin TM, Raymo ME (1997) Orbital forcing of deep-sea benthic species diversity. Nature 385:624-627

Dayton PK (1989) Interdecadal variation in an Antarctic sponge and its predators from oceanographic climate shifts. Science 245:1484-1486

Dayton PK (1990) Polar benthos. In: Smith WO (ed) Polar oceanography, part B: chemistry, biology and geology. Academic Press, London, p 631-685

Dayton PK, Hessler RR (1972) The role of biological disturbance in maintaining diversity in the deep sea. Deep-Sea Res 19:199-208

Dayton PK, Robilliard GA, Paine RT (1970) Benthic faunal zonation as a result of anchor ice formation at McMurdo Sound, Antarctica. In: Holdgate MW (ed) Antarctic ecology. Academic Press, London, p 244-257

Dayton PK, Newman WA, Paine RT, Dayton LB (1974) Ecological accommodation in the benthic community at McMurdo Sound, Antarctica. Ecol Monogr 44:105-128

Dayton PK, Mordida BJ, Bacon F (1994) Polar marine communities. Am Zool 34:90-99

Dearborn JH (1968) Benthic invertebrates. Australian Natural History, Dec, 1968:134-139

Fleeger JW, Yung PO, Sun B (1995) Active and passive processes associated with initial settlement and postsettlement dispersal of suspended meiobenthic copepods. J Mar Res 53:609-645

Gallardo VA (1987) The sublittoral macrofaunal benthos of the Antarctic shelf. Environ Int 13:71-81

Gallardo VA, Castillo JG (1969) Quantitative benthic survey of the infauna of Chile Bay (Greenwich Island, South Shetland Islands). Gayana Zool 16:3-18

Gray JS (1997) Marine biodiversity: patterns, threats and conservation needs. Biodivers Conserv 6(1):153-175

Gutt J, Starmans A, Dieckman G (1996) Impact of iceberg scouring on polar benthic habitats. Mar Ecol Prog Ser 137 . 311-316 
Gutt J, Storch V, Arntz WE (1999) Benthosforschung im Südpolarmeer: Störung schafft Vielfalt. Biologie In Unserer Zeit (BIUZ) (in press)

Huston MA (1979) A general hypothesis of species diversity. Am Nat 113:81-101

Huston MA (1994) Biological diversity: the coexistence of species on changing landscapes. Cambridge University Press, Cambridge

Kendall MA, Aschan M (1993) Latitudinal gradients in the structure of macrobenthic communities: a comparison of Arctic, temperate and tropical sites. J Exp Mar Biol Ecol 172:157-169

Kvitek RG, Conlan KE, Iampietro PJ (1998) Black pools of death: hypoxic, brine-filled ice gouge depressions become lethal traps for benthic organisms in a shallow Arctic embayment. Mar Ecol Prog Ser 162:1-10

Lien R, Solheim A, Elverhøi A, Rokoengen K (1989) Iceberg scouring and sea bed morphology on the eastern Weddell Sea shelf, Antarctica. Polar Res 7:43-57

Luxmoore RA (1.981) PhD thesis, British Antarctic Survey, CNAA

MCCook LJ, Chapman ARO (1991) Community succession following massive ice-scour on a rocky intertidal shore recruitment, competition and predation during early primary succession. J Exp Mar Biol Ecol 154:137-169

Oliver JS, Slattery PN (1985) Effects of crustacean predators on species composition and population structure of softbodied infauna from McMurdo Sound, Antarctica. Ophelia 24:155-175

Paine RT, Vadas RL (1969) The effects of grazing by sea urchins Strongylocentrotus spp. on benthic algal populations. Limnol Oceanogr 14:710-719

Peck LS, Bullough LW (1993) Growth and population struc-

Editorial responsibility: Otto Kinne (Editor),

Oldendorf/Luhe, Germany ture in the infaunal bivalve Yoldia eightsi in relation to iceberg activity at Signy Island, Antarctica. Mar Biol 117 $235-241$

Pianka ER (1987) Evolutionary ecology. Harper \& Row, New York

Picken GB (1985) Marine habitats - benthos. In: Bonner WN, Walton DWH (eds) Key environments, Antarctica, Chap 3. Pergamon Press, Oxford, p 154-172

Poore GCB, Wilson GDF (1993) Marine species richness. Nature 361:597-598

Reimnitz E, Barnes PW (1975) Sea ice as a geological agent in the Beaufort Sea shelf of Alaska In: Reed JC, Sater JE (eds) Proc Symp Beaufort Sea Coast and Shelf Res. Arctic Inst N America, Calgary, p 301-354

Richardson MD, Hedgepeth JW (1977) Antarctic soft-bottom, macrobenthic community adaptations to a cold, stable, highly productive, glacially affected environment. In. Llano GA (ed) Adaptations within Antarctic ecosystems. Gulf Publ Co, Houston, p 181-196

Sherman KM, Coull BC (1980) The response of meiofauna to sediment disturbance. J Exp Mar Biol Ecol 46:59-71

Stanwell-Smith DP, Barnes DKA (1997) Benthic community development in Antarctica: recruitment and growth on settlement panels at Signy Island. J Exp Mar Biol Ecol 212: $61-79$

Thorson G (1957) Bottom communities (sublittoral and shallow shelf). Mem Geol Soc US 67:461-534

Vanhove S, Lee HJ, Beghyn D, Van Gansbeke D, Brockington $S$, Vinx $M$ (1998) The metazoan meiofauna in its biogeochemical environment: the case of an Antarctic coastal sediment. J Mar Biol Assoc UK 78:411-434

White MG (1984) Marine benthos. In: Laws RM (ed) Antarctic ecology. Academic Press, London, p 421-462

Submitted: August 14, 1998; Accepted: February 18, 1999 Proofs received from author(s): August 27, 1999 